Int. J. Environ. Res. Public Health 2007, 4(1), 23-27

International Journal of

Environmental Research and Public Health

ISSN 1661-7827

www.jorjerphorg

(c) 2007 by MDPI

\title{
Alterations in the Concentrations of Liver Mitochondrial DNA, Cytoplasmic Total Hydrocarbon and Calcium in Guinea Pigs after Treatment with Nigerian Light Crude Oil
}

\author{
Ibiba F. Oruambo* and Adirimo B. Jones \\ Department of Chemistry, Rivers State University of Science and Technology Nkpolu-Port Harcourt, Rivers State, Nigeria \\ *Correspondence to Dr. Ibiba F. Oruambo. E-mail: ibibaforuambo@yahoo.com
}

Received: 12 December 2006 / Accepted: 15 February 2007 / Published: 31 March 2007

\begin{abstract}
The alteration of cellular calcium sequestration has been postulated to be a primary mechanism in the initiation of irreversible cell damage. Crude oil has been shown to cause concentration- dependent inhibition of calcium influx and mitochondrial swelling which may relate to its toxicity. Nigerian 'Bonny' Light Crude Oil (BLCO) is produced in the Niger-Delta region of Nigeria where oil spills are frequent and can endanger human-health, yet BLCO has not been studied in this regard. We have studied the effects of two doses of BLCO on mitochondrial DNA (mt.DNA), cytoplasmic total hydrocarbon concentrations (cyt.THC) and cytoplasmic $\mathrm{Ca}^{2+}$ (cyt.Ca ${ }^{2+}$ ) concentrations in livers of adult male guinea pigs exposed by intraperitoneal injection. The results showed that at $2.5 \mathrm{and} 5.0$ (ml/kg bw), BLCO caused dose-related increases in mt.DNA concentrations $(128 \%$ and $485 \%)$ respectively over the controls, and cyt.THC (47.5\% and 100\%) respectively; while it caused near-100\% decrease in cyt.Ca ${ }^{2+}$ concentrations $(94 \%$ and $96.8 \%$ ) respectively lower than the controls. These results suggest that BLCO caused the increased availability of crude oil hydrocarbons in the liver cells, and subsequent induction of unscheduled mt.DNA synthesis, and alteration of mitochondrial/endoplasmic reticulum $\mathrm{Ca}^{2+}$ sequestration or $\mathrm{ca}^{2+}$ - concentration gradient, leading to the inhibition of $\mathrm{Ca}^{2+}$ influx into the cytosol. These events may explain the probable hepatotoxicity of BLCO.
\end{abstract}

Keywords: Mitochondrial DNA: cytoplasmic total hydrocarbon, cytoplasmic $\mathrm{Ca}^{2+}$, bonny light crude oil.

\section{Introduction}

Crude oils are complex mixtures of a vast number of individual chemical compounds, the bulk of which are hydrocarbons [1]. Nigerian 'light' crude oil, commonly referred to as 'Bonny' light crude oil (BLCO) has a higher content of aliphatic hydrocarbon (light fraction) than aromatic hydrocarbon (heavy fraction) in an 80:20 ratio, thus it is referred to as 'light' crude oil (Nigerian National Petroleum Corporation - NNPC, personal communication). It is Nigeria's major foreign exchange earner and is produced exclusively in the Niger-Delta region of Nigeria where unfortunately oil spillages occur frequently which endanger human-health and the eco-system.

Although diverse toxicity studies have been reported on various geological crude oils, such as effects to various enzyme activities and calcium sequestration in ATP synthesis, studies on mitochondrial DNA (mt.DNA) have not been reported. Furthermore, an extensive internet search showed no references to such studies on BLCO.
For instance, 15-fold increase in dermal benzo(a)pyrene 3-hydroxylase activity after the application of Kuwaiti crude oil $(0-200 \mu \mathrm{g})$ to the skin of male Sprague-Dawley rats has been reported [2]; while the oral administration with Prudhoe Bay crude oil to SpragueDawley rats $24 \mathrm{~h}$ after treatment showed the inhibition of platelet aggregation by aliphatic, heterocylic and aromatic fractions of the crude oil [3].

Furthermore, alteration of cellular calcium sequestration has been postulated to be a primary mechanism in the initiation of irreversible cell damage [4]: the administration of $5 \mathrm{ml} / \mathrm{kg}$ bw Prudhoe Bay Crude Oil intraperitoneally or orally daily for two days to male Sprague-Dawley rats resulted in an abrupt drop in liver mitochondrial and microsomal adenosine triphosphatedependent calcium uptake [4]. In addition, in vitro incubation of either mitochondria or microsomes with crude oil extracts resulted in a concentration-dependent inhibition of calcium influx and produced swelling of mitochondria [4]. 
In a recent study, we reported that the concentration of crude oil total hydrocarbons (COTH) increased in a dose-related manner in the lungs more than in the liver at $2.5 \mathrm{ml} / \mathrm{kg}$ bw, but was higher in the liver than the lungs at $5.0 \mathrm{ml} / \mathrm{kg}$ bw when BLCO was administered to adult male guinea pigs by intraperitoneal injection (i.p) and that the specific activity of the mitochondrial 'marker' enzyme, succimic dehydrogenase increased markedly at $5.0 \mathrm{ml} / \mathrm{kg}$ bw over the untreated controls [5]. Also, in two yet-to-be published studies, we determined that BLCO caused significant, dose-related, increases in total cellular DNA and chromatin (nuclear) DNA in the liver of adult male guinea-pigs treated by i.p with $1.25,2.50$ and $5.0(\mathrm{ml} / \mathrm{kg}$ bw) BLCO, and induced significant increases in glucose-6phosphatase activity and regenerative DNA concentration in partially hepatectomized rat liver.

In this study, as a follow-up and in an effort to continue to understand the probable molecular pathway(s) of BLCO potential hepatotoxicity, we aimed to determine whether or not BLCO, when administered to male adult guinea-pigs at 2.5 and $5.0(\mathrm{ml} / \mathrm{kg} \mathrm{bw})$ by i.p. for two consecutive days would result in dose-related increases in liver cytoplasmic total hydrocarbon concentration (cyt.THC) and concomitant alterations in mitochondrial DNA (mt.DNA) and cytoplasmic $\mathrm{Ca}^{2+} \quad\left(\right.$ cyt.Ca $\left.{ }^{2+}\right)$ concentrations.

\section{Materials and Methods}

\section{Crude Oil}

Fresh Nigerian (Bonny) Light Crude Oil (BLCO) was obtained from the Nigerian National Petroleum Corporation (NNPC) here in Port Harcourt, Rivers State, Nigeria, and brought to the laboratory in an amber bottle.

\section{Treatment of Animals}

Fifteen adult male guinea-pigs each weighing between 300 and $350 \mathrm{gm}(0.3$ and $0.35 \mathrm{~kg})$ were used for the experiment and separated into three groups of five animals per group. The first group each received $2.5 \mathrm{ml} / \mathrm{kg}$ bw of BLCO by intraperitoneal (i.p) injection; the second group each received $5.0 \mathrm{ml} / \mathrm{kg}$ bw BLCO also by i.p.; while the third group was not treated and served as the control. Treatment was for two consecutive days and all animals were given rodent chow and drinking water ad libitum throughout the duration of the experiment.

All animals were sacrificed on the third day and their livers were pooled by group and homogenized to $10 \%$ $(\mathrm{w} / \mathrm{v})$ in ice-cold $0.05 \mathrm{M}$ potassium phosphate buffer, $\mathrm{pH}$ 74 , containing $0.2 \mathrm{mM}$ EGTA.

\section{Isolation and Quantification of mt.DNA}

The homogenate of each group was centrifuged at $1000 \mathrm{x} \mathrm{g}$ for $10 \mathrm{~min}$ to sediment the nuclei; the resultant supernatant was collected and re-centrifuged at 3,000 x g for $10 \mathrm{~min}$ to sediment the mitochondria. The resultant pellet was collected and washed twice in $0.05 \mathrm{M}$ potassium phosphate, $0.2 \mathrm{mM}$ EGTA buffer, $\mathrm{pH} 7.4$ and recentrifuged at $3,000 \mathrm{x}$ g for $10 \mathrm{~min}$ each time. DNA was subsequently extracted from the mitochondrial fraction by the phenol - chloroform extraction method and quantified by the diphenylamine method as described elsewhere [6].

Extraction and Quantification of Cytoplasmic (Extramitochondrial) Total Hydrocarbon

The resultant supernatant from the $3000 \mathrm{x} \mathrm{g}$ centrifugation which contained microsomes (endoplasmic reticulum -ER), lysosomes, etc. represented the cytoplasmic fraction which was collected and split for total hydrocarbon extraction and quantification and $\mathrm{Ca}^{2+}$ concentration quantification.

Total hydrocarbon was extracted with toluene and the concentration was determined in the toluene fraction by the absorbance at $420 \mathrm{~nm}$ against a standard calibration curve of known concentrations of n-hexane as described elsewhere [5].

Quantification of Cytoplasmic (Extra-mitchondrial) $\mathrm{Ca}^{2+}$

The concentration of calcium was determined in the split portion of the $3000 \mathrm{x}$ g supernatant, of each group, by the EDTA-titrimetric method [7].

\section{Statistical Analysis}

To ensure reproducibility of the results, each biochemical experiment i.e. quantification of mt.DNA (diphenylamine reaction), quantification of cyt.THC (absorbance at $420 \mathrm{~nm}$ ), and quantification of cyt.Ca ${ }^{2+}$ (EDTA-titrimetry), were done in two sets of triplicates, and the Arithmetic Means with their corresponding standard deviations were calculated. The Results are expressed as Mean \pm SD.

The magnitude of change of each parameter under study over control was calculated in percentage and expressed as percentage increase or percentage decrease.

\section{Results}

Table 1 shows the effect of dose of BLCO on liver mitochondrial DNA concentration in guinea-pigs treated by intra-peritoneal injection with $2.5 \mathrm{ml} / \mathrm{kg}$ bw and 5.0 $\mathrm{ml} / \mathrm{kg}$ bw for two consecutive days. There was a $128 \%$ increase in mt.DNA concentration at $2.5 \mathrm{ml} / \mathrm{kg}$ bw of BLCO over the untreated control $(0.16 \mathrm{mg} / \mathrm{ml}$ over 0.07 $\mathrm{mg} / \mathrm{ml}$ ) respectively: thus, mt.DNA concentration increased by $279 \%$ at $5.0 \mathrm{ml} / \mathrm{kg}$ bw over that at $2.5 \mathrm{ml} / \mathrm{kg}$ bw, (i.e. $0.41 \mathrm{mg} / \mathrm{ml}$ over $0.16 \mathrm{mg} / \mathrm{ml}$ ), a near-classic doseresponse relationship.

In Table 2, a similar dose-response pattern is evident as the cyt.THC at $2.5 \mathrm{ml} / \mathrm{kg}$ bw BLCO is $47.5 \%$ higher than the control, and $100 \%$ higher at $5.0 \mathrm{ml} / \mathrm{kg}$ bw than the control; the extent of increase at $5.0 \mathrm{ml} / \mathrm{kg}$ bw over that at 
$2.5 \mathrm{ml} / \mathrm{kg}$ bw is $35.6 \%$, again a near-classic dose-response. Thus, BLCO resulted in marked increases in liver cyt.THC in guinea-pigs treated with BLCO by i.p.

Table 1: Dose-related Mitochondrial DNA (mt.DNA) Concentrations in Livers of Adult Male Guinea-pigs Treated with $2.5 \mathrm{ml} / \mathrm{kg}$ bw and $5.0 \mathrm{ml} / \mathrm{kg}$ bw BLCO by intraperitoneal injection for two consecutive days.

\begin{tabular}{lcr}
\hline Dose $(\mathrm{ml} / \mathrm{kg} \mathrm{bw})$ & $\begin{array}{c}\text { mt.DNA } \\
\text { concentration } \\
(\mathrm{mg} / \mathrm{ml})\end{array}$ & $\begin{array}{r}\text { Percent Increase } \\
\text { over control }\end{array}$ \\
\hline Nil (Control) & $0.07 \pm 0.01$ & 128 \\
2.5 & $0.16 \pm 0.008$ & 485 \\
5.0 & $0.41 \pm 0.12$ & \\
\hline
\end{tabular}

Table 2: Dose-related increases in cytoplasmic Total Hydrocarbon Concentration (cyt.THC) In Livers of Adult Male Guinea-pigs Treated with $2.5 \mathrm{ml} / \mathrm{kg}$ bw and 5.0 $\mathrm{ml} / \mathrm{kg}$ bw BLCO by intraperitoneal injection for two consecutive days.

\begin{tabular}{lcr}
\hline Dose $(\mathrm{ml} / \mathrm{kg} \mathrm{bw})$ & $\begin{array}{c}\text { Cytoplamic THC } \\
(\mu \mathrm{g} / \mathrm{ml})\end{array}$ & $\begin{array}{r}\text { Percent Increases } \\
\text { over control }\end{array}$ \\
\hline Nil (Control) & $0.080 \pm 0.015$ & \\
2.5 & $0.118 \pm 0.006$ & 47.5 \\
5.0 & $0.160 \pm 0.04$ & 100 \\
\hline
\end{tabular}

Finally, the result in Table 3 shows the effects of increased doses of BLCO $(2.5 \mathrm{ml} / \mathrm{kg}$ bw and $5.0 \mathrm{ml} / \mathrm{kg} \mathrm{bw})$ on the concentration of extra-mictochondrial (cytoplasmic) calcium which does not follow the dose-related patterns in Tables 1 and 2; instead there were substantial decreases in cyt. $\mathrm{Ca}^{2+}$ concentrations at both dose levels in a dose independent manner: $94.0 \%$ and $96.8 \%$ respectively lower than the untreated controls $(0.086 \mathrm{~g} / \mathrm{l}: 1.437 \mathrm{~g} / \mathrm{l}$; and 0.046 $\mathrm{g} / \mathrm{l}: 1.437 \mathrm{~g} / \mathrm{l}$ at $2.5 \mathrm{ml} / \mathrm{kg}$ bw and $5.0 \mathrm{ml} / \mathrm{kg}$ bw BLCO) respectively.

Table 3: Cytoplasmic (Extra-mitochondrial) Calcium Concentration in Livers of Male Adult Guinea-pigs Treated with $2.5 \mathrm{ml} / \mathrm{kg}$ bw and $5.0 \mathrm{ml} / \mathrm{kg}$ bw BLCO by intraperitoneal injection for two consecutive days.

\begin{tabular}{lrrr}
\hline Dose $(\mathrm{ml} / \mathrm{kg} \mathrm{bw})$ & $\begin{array}{r}\text { Cytoplamic Ca } \\
\text { Concentration }(\mathrm{g} / \mathrm{l})\end{array}$ & $\begin{array}{r}\text { Percent decreases } \\
\text { over control }\end{array}$ \\
\hline Nil (Control) & 1.437 & \pm 0.09 & \\
2.5 & 0.086 & \pm 0.03 & 94 \\
5.0 & 0.046 & \pm 0.01 & 96.8 \\
\hline
\end{tabular}

\section{Discussion}

The results from this study show that BLCO, when given to adult male guinea-pigs by intraperitoneal injection at two varying doses of $2.5 \mathrm{ml} / \mathrm{kg}$ bw and $5.0 \mathrm{ml} / \mathrm{kg} \mathrm{bw}$, caused large dose-related increases in the concentrations of liver mt.DNA and cyt.THC; while it caused equally large, but dose-independent decreases in cyt.Ca ${ }^{2+}$ concentrations in the livers of treated, when compared to untreated control animals. The inter-relationship of increases in mt.DNA and cyt.THC on the one hand, and decreases in cyt.Ca ${ }^{2+}$ concentration on the other, may be relevant to understanding the implications of these effects. Mt.DNA, although it replicates independently of nuclear DNA, codes for some proteins that participate in mitochondrial and cellular metabolism. Although its concentration is much lower than that of nuclear DNA, when the mitochondrion divides, its DNA content at this stage increases to levels above nuclear DNA concentration. Since mt.DNA and cyt.THC are both increased in a dose-related manner, it is likely that BLCO was bio-transformed to metabolites that induced unscheduled mt.DNA synthesis. This aspect has not been done before; therefore the precise pathway is not clear from these results. The effect on cytoplasmic $\mathrm{Ca}^{2+}$ concentration may have implications for ATP synthesis. When ATP (Adenosine tri-phosphate) levels, coupled with low blood glucose concentration, deplete the liver exports new glucose molecules to tissues, such as, skeletal muscle or brain via the blood. Here, $\mathrm{Ca}^{2+}$ serves as a second messenger to hormonal bio-signal that triggers a cascade reaction in the liver which culminates in the activation of glycogen phosphorylase, which in turn breaks down liver glycogen to release glucose for export, say to skeletal muscle for glycolysis and ATP synthesis.

Normally, $\mathrm{Ca}^{2+}$ is sequestered in the mitochondria and/or endoplasmic reticulum (ER/microsomes) thereby keeping cytosolic $\left[\mathrm{Ca}^{2+}\right]$ very low by the action of $\mathrm{Ca}^{2+}$ pumps located in the ER, mitochondria and plasma membranes. The hormonal stimulus just described can cause either an influx of extra-cellular $\mathrm{Ca}^{2+}$ into the liver cell through the plasma membrane or release of sequestered $\mathrm{Ca}^{2+}$ from the mitochondria or ER; in either case, raising the intra-cellular (cytosolic) $\mathrm{Ca}^{2+}$ concentration which then triggers the sequence of cascade reactions for the breakdown of glycogen and release of glucose. It would appear therefore that perhaps there is a $\mathrm{Ca}^{2+}$-concentration gradient which acts to trigger the calcium pumps for $\mathrm{Ca}^{2+}$ influx or release.

One study had reported a crude oil concentrationdependent inhibition of calcium influx into the mitochondria for sequestration, and the production of swelling of the mitochondria in vitro, while postulating that alteration of cellular calcium sequestration may be the primary mechanism in initiating irreversible cell damage [4].

In another study, the administration of $5 \mathrm{ml} / \mathrm{kgbw}$ Prudhoe Bay crude oil intraperitoneally or orally daily for two days to male Sprague-Dawley rats that were sacrificed $24 \mathrm{~h}$ later resulted in an abrupt drop in liver mitochondrial and microsomal adenosine-triphosphate-dependent calcium 
uptake, while the in vitro incubation of either mitochondria or microsomes with dimethyl sulfoxide (DMSO) extracts of the crude oil resulted in a concentration-dependent inhibition of calcium influx [4].

The study concluded that their results indicate that increased permeability of the mitochondrial and microsomal membranes to calcium is a contributing factor in the inhibition of calcium uptake by Prudhoe Bay crude oil.

Our results seem to agree in part with this conclusion. In our study, BLCO caused a near- $100 \%$ decrease in cytoplasmic $\mathrm{Ca}^{2+}$ concentration at both $2.5 \mathrm{ml} / \mathrm{kg}$ bw and $5.0 \mathrm{ml} / \mathrm{kg}$ bw BLCO. We suggest that, perhaps $\mathrm{Ca}^{2+}$ influx and/or release from the mitochondrial or ER (microsomes) may have been inhibited or altered. Therefore, BLCO may have caused either damage to mitochondrial, ER and/or plasma membrane structure such that normal control level of cytosolic $\mathrm{Ca}^{2+}$ leached-out to perhaps elevate extracellular, $\mathrm{Ca}^{2+}$ level while decreasing intra-cellular (cytoplasmic) $\mathrm{Ca}^{2+}$ level. Alternatively, BLCO may have altered the $\mathrm{Ca}^{2+}$ - concentration gradient across the plasma membrane and/or mitochondrial membrane such that the calcium pumps are disabled which in turn disorganized the permeability of the plasma membrane and/or the mitochondrial membrane, thus inhibiting or nullifying $\mathrm{Ca}^{2+}$ uptake. Ultimately the implication of these results to the liver cell may be the alteration of hormonal bio-signal in which $\mathrm{Ca}^{2+}$ serves as second messenger thus inhibiting ATP-synthesis and perhaps cell and tissue damage. This could have toxic consequences for key organs that rely on the liver for glucose, such as skeletal muscle, brain etc.

A different study on crude oil-induced hepatotoxicity had shown that the oral administration of Prudhoe Bay crude oil at $5.0 \mathrm{ml} / \mathrm{kg}$ daily for two days to male Charles River CD1 mice resulted in increases in liver weight, hepatic proteins, RNA, glycogen, total lipids, cholesterol, triglycerides and phospholipids [8]. While this study did not include the effect to nuclear and/or mt.DNA concentration, its findings, vis-àvis the concentration-induction effects of crude-oil (Prudhoe Bay) on critical hepatic cellular macromolecules, such as proteins, ribonucleic acid (RNA), etc. are in agreement with out findings. Mt.DNA may represent a molecular target of crude oil metabolites, as are RNA, nuclear DNA or proteins. Similarly, the increases in total lipids and phospholipids by Prudhoe Bay crude oil [8] may add support to our thesis that liver cellular membranes, such as plasma membrane may have been disrupted by BLCO such that the $\mathrm{Ca}^{2+}$ concentration gradient across the membrane may also have been disrupted.

In another study, the administration of a single oral dose $(5-10 \mathrm{ml} / \mathrm{kg} \mathrm{bw})$ of Prudhoe Bay Crude oil to pregnant Sprague-Dawley rats resulted in induction in maternal hepatic microsomal cytochrome P450 levels and various monooxygenases in a dose-dependent manner after $24 \mathrm{~h}$ [9]. In our study, we found that both mt.DNA concentration and cyt.THC were increased in a doserelated manner; and we earlier suggested the probable biotransformation of some BLCO components to reactive metabolites which may be responsible for the induction of mt.DNA concentration. The results of the cited study may support our results at least in theory, as they reported an oil-induced induction of hepatic microsomal cytochrome P450 levels and various monooxygenases which catalyze the phases I and II bio-transformation of polyaromatic aromatic hydrocarbons, such as benzo(a)pyrene, a known constituent of crude oil, including BLCO [1].

Finally, in a recent study of the hepatotoxic and hematological effects of BLCO in male albino rats, Orisakwe, O.E. et al reported that packed cell volume (PCV) and total white blood cell (WBC) were significantly decreased at $200 \mathrm{mg} / \mathrm{kg}$ of BLCO while at 200, 400 and $800 \mathrm{mg} / \mathrm{kg}$ BLCO caused significant dose-dependent increases in glutamic oxaloacetic transaminase (GPT) levels, but a significant decrease in the alkaline phosphatase (AP) level compared to the respective controls [10]. These results further suggest, as do our results, that BLCO may be potentially hepatotoxic.

In conclusion, we acknowledge that there may be other explanations and/or interpretation of our results, which however may be relevant in understanding the molecular mechanism(s) of crude oil- in particular BLCO, induced hepatotoxicity.

\section{References}

1. International Agency for Research on Cancer (IARC) Monographs. Occupational Exposures in Petroleum Refining; Crude Oil and Major Petroleum Fuels; 1989, vol. 45:120.

2. Rahimtula, A. D.; O'Brien, P. J.; Payne, J. F.: Induction of xenobiotic metabolism in rats on exposure to dydrocarbon- based oils. In: MacFarland, H. B.; Holdgworth, C. E.; MacGregor, J. A.; Call, R. W. \& Lane, M. L.; eds, Advances in Modern Environmental Toxicology, vol. VI, Applied Toxicology of Petroleum Hydrocarbons, Princeton Scientific Publishers, 1984, pp. 71-79.

3. Chaudhury, S.; Macko, S.; Rahimtula, A. D.: Ihibition of rat platelet aggregation by a Prudhoe Bay Crude Oil and its Aliphatic, Aromatic, and Heterocyclic Fractions. Toxicol. appl. Pharmacol, 1987, 90: 347-356.

4. Khan, S.; Payne, J. F.; Rahimtula, A. D.: Mechanisms of Petroleum Hydrocarbon Toxicity: Destruction of liver microsomal and mitochondrial calcium pump activities by Prudhoe Bay Crude Oil; J. Biochem. Toxicol. 1986, 1:31-43.

5. Oruambo, I. F.: Tissue and Subcellular Concentrations of Total Hydrocarbons, and Level of Hepatic Succinic Dehydrogenase Activity after Treatment of Guinea Pigs with Bonny Light Crude Oil. Global J. Environ. Sci. 2006, 5(1), 15-17.

6. Oruambo, I. F.: Alteration of glucose-6-phosphatase activity and regenerative DNA and total DNA concentrations in regenerating and normal rat liver of aqueous extracts of two Nigerian Plants. J. Environ. Pathol. Toxicol. and Oncol. 1989, 9/2: 191-199.

7. Hildebrand, G. P.; Reilley, C. N.: New indicator for complexometric titration of calcium in the presence of magnesium. Anal. Chem. 1957, 29: 258. 
8. Khan, S.; Irfan, M.; Rahimtula, A. D.: The hepatotoxic potential of a Prudhoe Bay crude oil: effect on mouse liver weight and composition. Toxicology, 1987, 46: 95 - 105.

9. Khan, S.; Martin, M.; Rahimtula, A. D.; Payne, J. F.: Effect of a Prudhoe Bay crude oil on hepatic and placental drug metabolism in rats. Can. J. Physiology.
Pharmacol, 1987, 65: 2400- 2408.

10. Orisakwe, O. E.; Akumka, D. D.; Njan, A. A.; Afonne, O. J.; Okechi, O. O.: Hepatotoxic and haematological effects of Nigerian Bonny light crude oil in male albino rats, in: Toxicological and Environmental Chemistry, Taylor and Francis Publishers, 2005, 87(2): 215-221. 